Portland State University

PDXScholar

$11-16-2018$

\title{
Establishing Baseline Lead Levels Found in Swiss Chard Grown Near the Hillsboro Airport
}

Amber A. Lee

Portland State University

Follow this and additional works at: https://pdxscholar.library.pdx.edu/honorstheses

Let us know how access to this document benefits you.

\section{Recommended Citation}

Lee, Amber A., "Establishing Baseline Lead Levels Found in Swiss Chard Grown Near the Hillsboro Airport" (2018). University Honors Theses. Paper 638.

https://doi.org/10.15760/honors.653

This Thesis is brought to you for free and open access. It has been accepted for inclusion in University Honors Theses by an authorized administrator of PDXScholar. Please contact us if we can make this document more accessible: pdxscholar@pdx.edu. 
Establishing Baseline Lead Levels found in Swiss Chard Grown Near the Hillsboro Airport

by

Amber A. Lee

An undergraduate honors thesis in partial fulfillment of the requirements for the degree of

Bachelor of Sciences

In

University Honors,

General Science,

and

Chemistry

Thesis Advisor

Dean Atkinson

Portland State University

2018 


\title{
Establishing Baseline Lead Levels found in Swiss Chard Grown Near the Hillsboro Airport
}

Amber A. Lee

\begin{abstract}
Samples of Swiss Chard were collected from four community gardens within a three-mile radius from the Hillsboro Airport in Hillsboro, Oregon. Samples were also collected from a site within a two-mile radius of the airport, as well as a removed site in McMinnville, OR. Samples were analyzed using Anodic Stripping Voltammetry (ASV) to quantify the lead content from each site. The highest concentration of lead was from the site within a two-mile radius of the airport with a value of $8.9 \times 10-4$ micrograms of lead per gram of sample. The lowest site concentration was $3.9 \times 10-5$ micrograms per gram from Sonrise Community Garden. A Tolerable Daily Intake (TDI) value established by the Joint Executive Council on Food Additives, World Health Organization, and the Food and Agriculture Organization was considered a safe lead threshold in this study. Lead content found in samples indicate that it would require the consumption of hundreds of pounds of Swiss Chard a day to exceed safe Pb levels. There was a negative correlation between lead concentration and distance from the Hillsboro Airport (Multiple $\mathrm{R}=-.67$ ) This study suggests the combustion of aviation fuel plays a very small role in the extent of lead exposure in Swiss Chard grown near flight-training facilities using aviation fuel.

\section{Introduction}

Lead is a soft, malleable heavy metal that is easily extracted from mining ores. Due to its relative abundance, low melting point, high density and its ability to oxidize, lead has been used in substances like gasolines, and paints. Though the toxicity of lead was not recognized until the late nineteenth century it has been widely distributed throughout the environment (Nriagu 1998; CDC 1991). This has made exposure to lead a more frequent occurrence than was once believed. It's suggested the level of toxicity in the environment released from trace metals is greater than both organic and radioactive pollutants (Mielke 1998.) Lead acts as a neurotoxin in the human body (Ryan et al. 2004.) Accumulating in bone, as well as soft tissue lead can lead to substantial damage to the nervous system and blood especially when exposure occurs in high levels over a long period of time. Though lead exposure is dangerous to all, it has adverse effects on developing children as well as pregnant women, or women of childbearing ages (Clark et al. 2008.) Lead absorption is deleterious in pregnant women and women able to bare children. Lead presence may affect both the health of the mother and baby because skeletal bone accumulates lead and can release the stored neurotoxin throughout gestation (Gomaa et al 2002.) The data suggest that lead exposure in children is associated with developmental
\end{abstract}


delay, decreased muscle and bone growth, problems with speech and language, damage to kidneys, and nervous system. In some cases with large exposure levels, seizures and unconsciousness have been documented (CDC 1997.)

While use of lead was outlawed as an additive in paint in 1971, and in gasoline in 1996 these sources continue to be responsible for the majority of the residential lead exposure (Rabinowitz et al. 2005.) Leaded gasoline-contaminated dust and lead-based paint dust can easily enter the body through inhalation, ingestion, and dermal absorption making it a multi-media pollutant. Lead contaminated dusts also contaminate surrounding surfaces and soil near the source of exposure. Lead additives were first combined with automobile gasoline in the early 1920's for its antiknock properties and its ability to assist with lubrication in piston engines (Nriagu 1989.) Shortly after its discovery, the most common fuel lead additive, Tetraethyllead (TEL) was produced in large scales, and distributed across the United States in the form of TEL gasoline. After combustion of TEL gasoline in the engine the product lead oxide leaves a small amount of residue trapped in the oil or on the internal surfaces of the automobile; however nearly $75 \%$ of the lead in the fuel is emitted from the exhaust pipe (U.S. EPA 1986.) Because lead is a heavy metal it does not decay or biodegrade. This means lead oxide dust is likely to remain in the lower atmospheric stratum making it a ubiquitous pollutant in urban settings where heavy traffic and high levels of industry occur (CDC 1991, U.S EPA 1998.)

Though lead was utilized in very common industrialized commercial and residential practices in the mid-twentieth century in 1971 the Lead Poisoning Prevention Act was passed which encouraged the federal government to ban leaded paint all together in 1978. Not too long after, the U.S Clean Air Act banned the sale and use of leaded automobile gasoline in 1996, and there the phase out of the leaded automobile fuel in the country began (U.S EPA 1996.) The phase out of leaded gasoline may have discontinued the future emission of lead from automobile gasoline into the environment, but could not remedy the lead that had been already emitted.

Though the majority of historical lead sources have been phased out there are still sources of lead present in leaded aviation fuel, or av-gas, used for small aircrafts. This source of lead exposure is often overlooked because many of the public are simply unaware of its use; however, there are numerous studies evaluating the effects of avgas lead emissions and lead exposure. The addition of lead is added to avgas as tetraethyl lead (TEL), which was the same lead additive utilized in the production of leaded automobile gasoline (Lovestead et al. 2009.) Unlike larger aircrafts which use a kerosene-based fuel, these smaller engine aircrafts using avgas add tetraethyl lead to obtain a higher-octane concentration, as well as to prevent knock and valve seat secession in piston-engine aircrafts similar to its uses in auto gas (Kessler 2013). Though many are familiar with historical lead point source exposures few are aware of the presence of leaded fuel used in the aviation community. The use of leaded aviation fuel is now the leading source of lead eminence in the United State (Miranda et al 2011.) In 2005 it was estimated that lead emissions from the use of leaded 
aviation gasoline comprises nearly half of the United States' inventory of lead atmospheric emissions (U.S EPA 2009.) Not all aviation fuels contain the same content of lead. 100 octane low lead is a commonly used, and available avgas that contains up to 2.12 grams of lead per gallon of fuel (ASTM 2005.) Aircrafts utilizing leaded aviation gasoline are often piston engine operating and can be used for instructional purposes, for-hire services, as well as personal and business use. Because avgas uses TEL, the same lead additive as leaded automobile gasoline, avgas provides the public with similar pathways of lead exposure such as inhalation, ingestion, and dermal absorption of small lead particles.

In the state of Oregon, a rural airport in Hillsboro was found to emit approximately 0.6 tons of lead from aviation activities in 2011 and was estimated to emit nearly 0.9 tons per year after an airport expansion (DEQ: Air Toxics Science Advisory Committee 2015.) The Hillsboro Airport is home to many small aircraft training flights, where flight patterns are circularly concentrated around the airport and its surrounding areas. With three runways, and a FAA air traffic control tower, this airport is home to the Hillsboro Aero Academy, and ATP Flight School. The Hillsboro Airport is not only central to the city of Hillsboro but is also surrounded by large global companies such as Intel, and Nike, which play a large role in growing the population in the area. The Portland International Airport is nearly $\mathbf{2 0}$ miles from Hillsboro city limits and for convivence cooperate businesses based out of Hillsboro may use flying services through the Hillsboro airport. The Hillsboro airport is the second busiest airport in the state of Oregon, and is considered an integral part of the Portland metro transportation system (Port of Portland 2018.)

Many residents are attracted to the Hillsboro area for its space and ability to accommodate a suburban lifestyle. Nearly 10 miles away from downtown Portland, OR, Hillsboro provides a tight-knit community. It is conveniently within reach of the ever-growing opportunity of industry in Oregon's largest city. With an expanding urban growth boundary, Portland Metro residents value urban gardening as a way to conserve agricultural space just outside of the urban boundary. Urban farming also encourages healthy eating, physical outdoor activity, and fosters a sense of community whether gardening in a community garden or a backyard garden. Growing produce in urban gardens is also a sustainable option for many in the Hillsboro area; however, with the increased atmospheric lead exposure near the airport are Hillsboro residents at risk? Once lead is released from the combustion of aviation fuel it enters the atmosphere. Once in the atmosphere the lead falls back down to the earth and settles in the exposed soil (Li et al. 2001.) The uptake of metals in vegetable crops is a well-researched topic; however, there is little research evaluating the phytoremediation of garden vegetables near lead emitting airports using av-gas (Woolson 1973.) There is data that suggest the ingestion of vegetables grown near high metal concentrations may pose a health risk to humans due to plants ability to uptake lead from soil or from direct desposition of lead contaminated dust (Cobb et al. 1999; Rahlenbeck et al. 1999; U.S EPA 1986.) Not all garden vegetables have the same tendency to pick up metals such as lead. Data suggest that lettuce and radishes tolerate higher concentrations of metals in 
soils (Cobb et al. 1999.) Some garden vegetables accumulate metals in the fruiting part of the plant while others for store metals in tissues that are considered inedible. A study by Finster et al. evaluated potential health hazards from the absorption of lead through garden vegetables grown in a lead contaminated neighborhood. Results also suggest edible root vegetables, and leafy vegetables contained the highest levels of lead in the biomass of the edible portions of the plant. Swiss Chard in particular was found to have the ability to accumulate high levels of lead without jeopardizing the viability of the plant (Rahlenbeck et al. 1999; Sterrett et al. 1996.) This study evaluates Swiss Chard because of this characteristic. What extent of lead exposure is found in Swiss Chard grown in community gardens near flighttraining airports using leaded aviation fuel? This study seeks to establish a baseline of lead concentrations found in Swiss Chard grown near the Hillsboro Airport. A review of the point sources, and bioavailability of lead will be discussed. When the role of lead contaminated dust from sources of leaded fuel are addressed as potential pathways for human heavy metal exposure, effective practices that can limit contact exposure can be tested and utilized.

\section{Methods}

\section{Sample Site Location}

\footnotetext{
Swiss Chard samples were collected from six collection sites in total. Four sites were the four community gardens located
}

in Hillsboro, Oregon. One sample site was a residential neighborhood backyard garden. The last sample site was from a local farm in McMinnville, Oregon. There are two community gardens located on the west side of the Hillsboro Airport, Calvary, and David Hill Community Gardens. There are also two gardens on the east side, Orenco and Sonrise Community Gardens. All gardens are within a three-mile radius of the airport. Figure 1 offers an illustration of the four community garden locations as well as well as the backyard garden in relation to the airport.

\section{Sample Recruitment}

The Community Garden Program Coordinator of the Hillsboro Parks and Recreation department was contacted in early May to inquire about potential Swiss Chard sample donations. Via email she notified community gardeners of the opportunity to volunteer samples to be collected, and used for this study. Once consent of participation was established samples were collected on an individual basis from each site. In this paper samples sites refer to the six locations samples were obtained, while samples represent plant donations given by individuals. There were ten samples donated in total. 


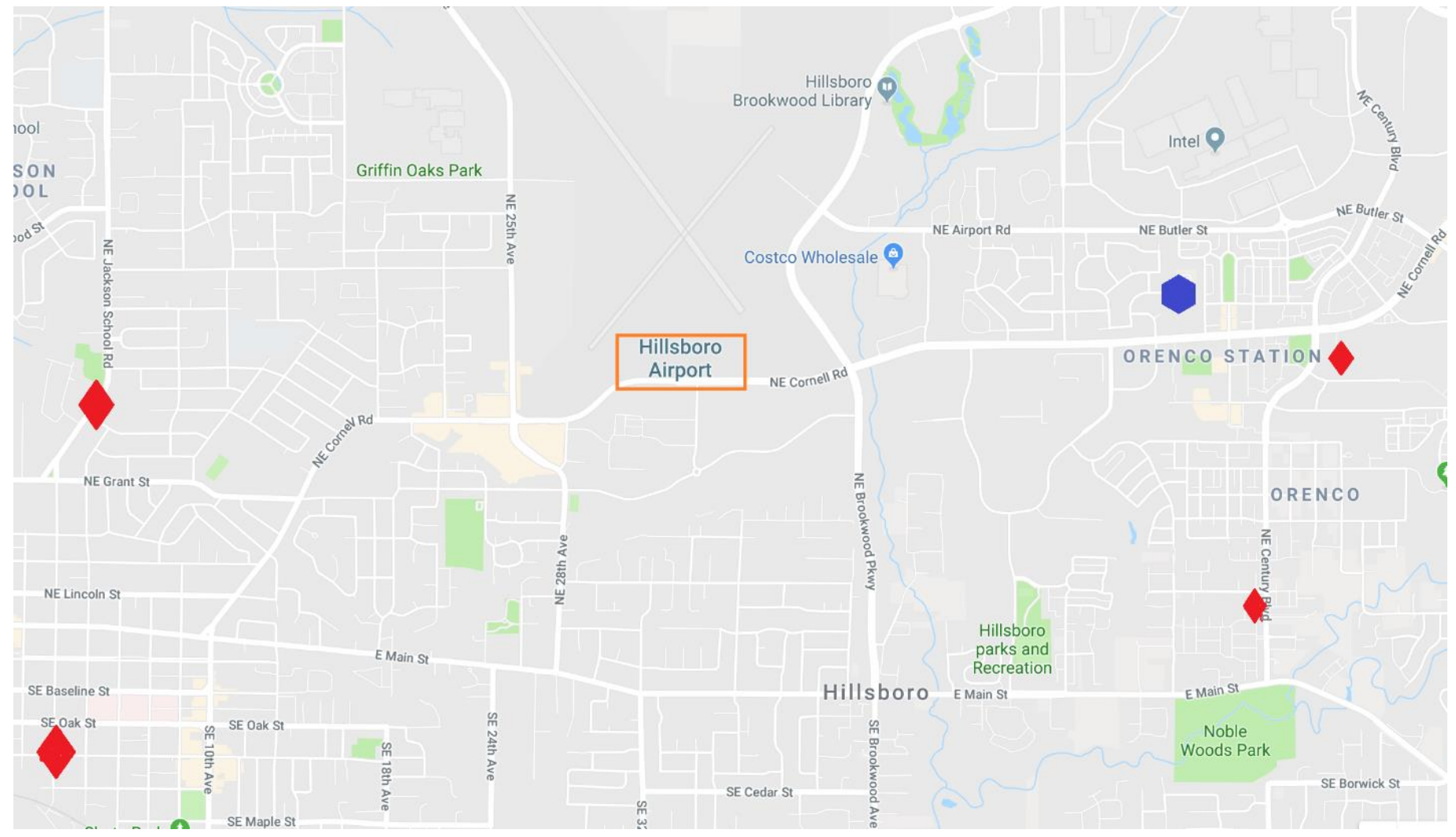

Figure 1: Illustration of experimental collection sites and their spacial proximity to the Hillsboro Airport, as well as major roadways. Red diamonds indicate Community Gardens, while the blue hexagon indicates the backyard sample site.

\section{Sample Collection}

Collection of Swiss Chard samples occurred in early June of 2018. Sampling included removing full mature leaves as well as 6 centimeters of the leaf's steam from near the base of the plant to represent edible portions of plant. Only healthy-looking leaves near the base of the plant were selected for sampling. Base leaves were chosen for this study because these are the leaves most likely to accumulate pollutants from the soil. Leaves and attached stems were placed in individual foil packets and refrigerated for 24 hours before digestion. Plants were grown in their respective sites for at least a month according to short interviews with the sample donors.

\section{Sample Preparation and Digestion}

Samples were rinsed with deionized water to remove possible residual soil contamination and left to air dry. Garden samples were then baked at $200{ }^{\circ} \mathrm{C}$ for up to three days to remove any water content. Dried contents of each sample, leaves and stems, were then pulverized in a small coffee grinder. Nearly half a gram of the pulverized sample was added to $10 \mathrm{~mL}$ of concentrated nitric acid. This mixture was gradually heated to $100^{\circ} \mathrm{C}$ in a shaking water bath for an hour. From there $1 \mathrm{~mL}$ increments of concentrated hydrogen peroxide were added to the nitric acid mixture every hour for nearly 4 hours until the digestion mixture was transparent. 
Instrument

The Anodic Stripping Voltammetry (ASV) instrument used for analysis was a PDV6000plus.

\section{Sample Analysis}

Digested plant samples were then analyzed using Anodic Stripping Voltammetry. This kind of voltammetry is used to quantify the ionic species in a sample using three electrodes: a working electrode, a reference electrode and an auxiliary electrode. The analyte is first electroplated on the working electrode during a process called desposition. Deposition uses a negative voltage to first plate a thin film of mercury over the glassy carbon working electrode. Once the sample is added to the cell the positively charged ions in the sample form an amalgam with the plated mercury. When plated on the working electrode the electrode can then be oxidized from in the stripping step. The instrument quantifies the oxidized substance as a peak once the specific oxidization potential of the lead is reached therefore stripping the lead off of the working electrode back into the solution. The current that is produced allows for the quantification of the metal concentration. Once the lead content of the sample was determined in parts per billion ( $p p b$ ) micrograms of lead per gram of Swiss Chard were determined for each sample, as well as each sample site.

\section{Data Analysis}

An average lead concentration for each plant sampled from was determined and used to find an average concentration for each sampling site. Using a Tolerable
Daily Intake (TDI) value established by The Joint Executive Council on Food Additives, World Health Organization, and the Food and Agriculture Organization, the amount of Swiss Chard needed to be consumed per day to exceed the TDI based on general American weight class. The TDI used was 3.5 micrograms of lead per kilogram of body weight (Clark et al. 2008.) This was adjusted for the body weight of children 2 to 6 years old to give 42 to 70 micrograms of lead per day to exceed the Tolerable Daily Intake (Glorennec 2006; Baars et al. 2001; JECFA 1999) The average weight of an American woman at $76.4 \mathrm{~kg}$, and man at $88.8 \mathrm{~kg}$ was used to calculate grams of Swiss Chard needed to consume daily to exceed the TDI threshold. The calculated values from sites near the Hillsboro Airport were compared to the McMinnville collection site because it was the only site removed from airport exposure. 


\section{Data}

Table 1: Calculated average lead content for each sample and sample site in micrograms of lead per gram of plant sample (ug/g). As well as the required amount of Swiss Chard in grams needed to consume a day to exceed Tolerable Daily Intake for a small child, larger child, average U.S woman and average U.S man.

\begin{tabular}{|c|c|c|c|c|c|}
\hline \multicolumn{6}{|c|}{ Collection Site Specific Average Lead Concentrations } \\
\hline Sample Names Averages & $\begin{array}{c}\text { Lead } \\
\text { Concentration } \\
(\mu / g)\end{array}$ & $\begin{array}{l}\text { Amount of } \\
\text { Chard to } \\
\text { meet TDI for } \\
\text { Small Child } \\
\text { (g) }\end{array}$ & $\begin{array}{l}\text { Amount of } \\
\text { Chard to } \\
\text { meet TDI for } \\
\text { Large Child } \\
\text { (g) }\end{array}$ & $\begin{array}{l}\text { Amount of } \\
\text { Chard to } \\
\text { meet TDI for } \\
\text { Average U.S } \\
\text { Woman (g) }\end{array}$ & $\begin{array}{l}\text { Amount of } \\
\text { Chard to } \\
\text { meet TDI for } \\
\text { Average U.S } \\
\text { Man (g) }\end{array}$ \\
\hline Calvary Plant \#1 & $2.1 \mathrm{E}-04$ & $3.2 \mathrm{E}+05$ & $5.3 \mathrm{E}+05$ & $2.0 \mathrm{E}+06$ & $2.4 \mathrm{E}+06$ \\
\hline Calvary Plant \#2 & $8.3 \mathrm{E}-05$ & $5.4 \mathrm{E}+05$ & $9.0 \mathrm{E}+05$ & $3.5 \mathrm{E}+06$ & $4.0 \mathrm{E}+06$ \\
\hline Calvary Site & $1.5 \mathrm{E}-04$ & $4.3 \mathrm{E}+05$ & $7.2 \mathrm{E}+05$ & $2.7 \mathrm{E}+06$ & $3.2 \mathrm{E}+06$ \\
\hline Sonrise Plant \#1 & $1.3 \mathrm{E}-05$ & $3.7 \mathrm{E}+06$ & $6.2 \mathrm{E}+06$ & $2.4 \mathrm{E}+07$ & $2.7 \mathrm{E}+07$ \\
\hline Sonrise Plant \#2 & $6.1 \mathrm{E}-06$ & $1.2 \mathrm{E}+07$ & $2.0 \mathrm{E}+07$ & $7.5 \mathrm{E}+07$ & $8.7 \mathrm{E}+07$ \\
\hline Sonrise Plant \#3 & 9.7E-05 & $4.6 \mathrm{E}+05$ & $7.7 \mathrm{E}+05$ & $3.0 \mathrm{E}+06$ & $3.4 \mathrm{E}+06$ \\
\hline Sonrise Site & $3.9 \mathrm{E}-05$ & $5.3 \mathrm{E}+06$ & $8.8 \mathrm{E}+06$ & $3.4 \mathrm{E}+07$ & $3.9 \mathrm{E}+07$ \\
\hline Orenco Plant \#1 & $1.0 \mathrm{E}-04$ & $4.3 E+05$ & $7.2 \mathrm{E}+05$ & $2.7 \mathrm{E}+06$ & $3.2 \mathrm{E}+06$ \\
\hline Orenco Site & $1.0 \mathrm{E}-04$ & $4.3 \mathrm{E}+05$ & $7.2 \mathrm{E}+05$ & $2.7 \mathrm{E}+06$ & $3.2 \mathrm{E}+06$ \\
\hline David Hill Plant \#1 & $8.5 \mathrm{E}-05$ & $6.0 \mathrm{E}+05$ & $1.0 \mathrm{E}+06$ & $3.8 \mathrm{E}+06$ & $4.4 \mathrm{E}+06$ \\
\hline David Hill Plant \#2 & $1.4 \mathrm{E}-04$ & $3.9 \mathrm{E}+05$ & $6.5 \mathrm{E}+05$ & $2.5 \mathrm{E}+06$ & $2.9 \mathrm{E}+06$ \\
\hline David Hill Site & $1.1 \mathrm{E}-04$ & $4.9 \mathrm{E}+05$ & $8.2 \mathrm{E}+05$ & $3.1 \mathrm{E}+06$ & $3.6 \mathrm{E}+06$ \\
\hline Backyard Garden Site & $8.9 \mathrm{E}-04$ & $6.5 \mathrm{E}+05$ & $1.1 \mathrm{E}+06$ & $4.1 \mathrm{E}+06$ & $4.8 \mathrm{E}+06$ \\
\hline McMinnville Site & $1.4 \mathrm{E}-04$ & $2.3 \mathrm{E}+06$ & $3.8 \mathrm{E}+06$ & $1.5 \mathrm{E}+07$ & $1.7 \mathrm{E}+07$ \\
\hline
\end{tabular}


Table 2: Pounds of Swiss Char required to consume daily to exceed Tolerable Daily intake for average U.S woman, and average U.S man.

\begin{tabular}{|c|c|c|}
\hline \multicolumn{3}{|c|}{ Collection Site Specific Average Lead Concentrations } \\
\hline Sample Names Averages & $\begin{array}{l}\text { Amount of } \\
\text { Chard to } \\
\text { meet TDI for } \\
\text { Average U.S } \\
\text { Woman (lbs) }\end{array}$ & $\begin{array}{l}\text { Amount of } \\
\text { Chard to } \\
\text { meet TDI for } \\
\text { Average U.S } \\
\text { Man (Ibs) }\end{array}$ \\
\hline Calvary Plant \#1 & $5.2 \mathrm{E}+03$ & $4.5 \mathrm{E}+03$ \\
\hline Calvary Plant \#2 & $8.9 \mathrm{E}+03$ & $7.6 \mathrm{E}+03$ \\
\hline Calvary Site & $7.0 \mathrm{E}+03$ & $6.0 \mathrm{E}+03$ \\
\hline Sonrise Plant \#1 & $6.0 \mathrm{E}+04$ & $5.2 E+04$ \\
\hline Sonrise Plant \#2 & $1.9 \mathrm{E}+05$ & $1.7 \mathrm{E}+05$ \\
\hline Sonrise Plant \#3 & $7.6 \mathrm{E}+03$ & $6.5 \mathrm{E}+03$ \\
\hline Sonrise Site & $8.7 \mathrm{E}+04$ & $7.4 \mathrm{E}+04$ \\
\hline Orenco Plant \#1 & $7.0 \mathrm{E}+03$ & $6.1 \mathrm{E}+03$ \\
\hline Orenco Site & $7.0 \mathrm{E}+03$ & $6.1 \mathrm{E}+03$ \\
\hline David Hill Plant \#1 & $9.8 \mathrm{E}+03$ & $8.4 \mathrm{E}+03$ \\
\hline David Hill Plant \#2 & $6.3 \mathrm{E}+03$ & $5.4 \mathrm{E}+03$ \\
\hline David Hill Site & $8.0 \mathrm{E}+03$ & $6.9 \mathrm{E}+03$ \\
\hline Backyard Garden Site & $1.1 \mathrm{E}+04$ & $9.1 \mathrm{E}+03$ \\
\hline McMinnville Site & $3.8 \mathrm{E}+04$ & $3.2 \mathrm{E}+04$ \\
\hline
\end{tabular}

\section{Results}

Data analysis suggests that all samples of Swiss Chard collected contained a safe amount of lead in the edible plant tissues. The highest concentration of lead found in Swiss Chard tissue was 8.9X10-4 micrograms of lead per gram of sample from the residential collection site within a 2-mile radius of the Hillsboro Airport. This concentration is considerably low and would require the average American woman to consume nearly 11,000 pounds of Swiss Chard daily to exceed the Tolerable Daily Intake threshold.

Looking at the data collected from the four Hillsboro community gardens Calvary Community Garden on the West side of the Airport had the second highest levels of lead in plant tissue with an average value of 1.5X10-4 micrograms of lead per gram of plant sample. David Hill Community Garden, which is also located on the West side of the airport, follows with an average value of 1.1X10-4 micrograms per gram. 
Samples from Orenco Community Garden

had a slightly smaller concentration of lead with 1.0X10-4 micrograms per sample, while the Sonrise Community Garden collection site had the overall smallest amount of lead per gram of sample. Though very slight there the two gardens located on the west side of the Hillsboro Airport both had higher lead concentrations than that of the east side of the airport.

Data collected from the site removed from the Hillsboro Airport in McMinnville was found to have a higher lead concentration than the Sonrise Community Garden, Orenco Community Garden as well as David Hill Community Garden.

Table 2 illustrates the amount of Swiss Chard an average sized woman and man would need to consume daily to exceed safe levels of lead intake based on the lead concentrations determined for each sample and sample site. For men woman, and children from the U.S. it would require the ingestion of thousands of pounds of the chard that was sampled to exceed a recommended tolerable intake.

The negative correlation between the average lead concentration and the sample site's distance from the Hillsboro Airport suggest that the airport, though a possible source of environmental lead pollution, does not jeopardize the health of backyard garden vegetable consumers.

\section{Discussion}

All community gardens plots collected from are relatively removed from historical sources of lead contamination such as busy roadways, and residential neighborhoods built before the 1970's; however, the two gardens to the west of the airport are positioned closer to roadways than the two gardens to the east of the airport. Evidence from previous studies evaluating lead exposure through garden vegetables exposed to lead contaminated dust suggest a positive correlation between lead levels in vegetable mass and distance from lead point sources like roads, and residential neighborhoods with a history of lead-based paint. Though a positive correlation was not observed in this study, data from this study indicates higher lead levels in Swiss Chard from the two community gardens on the west side of the airport. These two particular gardens were closer in proximity to roadways compared to the eastern community gardens however patterns of rain water run-off could also be a contributing factor. It is unlikely that the higher lead levels in the western gardens were from sources of leaded paint.

Evaluating the prevailing wind direction near the Hillsboro Airport could give us more insight as to why some garden locations reported higher lead concentrations than others. Samples were collected in early June. During this time of the year prevailing winds direct to the Northwest, which could encourage lead in the atmosphere to relocate Northwest of the point source. The lead contamination from house paint is often found in the form of large chips of paint unless removal of leaded paint during residential demolition or renovation was not contained properly. A review from Mielke et al. suggests that 
lead contaminated dust from automobile gasoline is a greater source of lead exposure compared to leaded house paint. The backyard urban garden closest to the Hillsboro Airport had the highest levels of lead. This small garden was grown in a raised garden bed with purchased soil, and was in a newly developed residential neighborhood so the chances of lead contamination from leaded exterior paint is unlikely in this situation.

Finester et al. found a pattern of lead uptake in garden plants from the soil up the root, the shoot, and to the lower leaves. Many vegetables do not tend to accumulate heavy metals in the edible portions of the plant; however, these findings do not indicate that lead presence in the inedible portions signify safe consumption. There has not been an established amount of lead that is considered safe in the bloodstream (CDC, 2007; U.S. EPA 2006.) Because of this, many experts advise taking additional measures during garden preparation to ensure the quality of produce especially in areas with identified point sources of lead. Some small gardening practices can limit the overall exposure to soil and atmospheric pollutants. Recommendations for leadmitigation in gardens suggest that residential gardeners should use storebought soil tests to evaluate soil conditions before planting garden crops. If a considerable amount of heavy metals in the soil experts suggest the use of a raised garden bed and a semi-permeable membrane between contaminated soil and fresh bed soil. Refrain from using open compost piles in areas with a history of lead contaminated dust exposure because the open soil may accumulate higher levels of lead. Produce harvested from backyard or urban gardens should be washed before consumption or even washed with a low concentrated detergent mixture. Though consumers can wash remnants of lead contaminated dust or soil off home grown garden vegetables, it cannot remedy the lead levels that have been already integrated through direct uptake. It is recommended taking extra precaution when tending to a garden near sources of contamination.

Young children are more likely to experience lead exposure in areas open to lead contaminated dust from the combustion of TEL containing gasoline due to hand to mouth habits as well as pica. Pica is the desire to consume inedible objects such as soil, plastic, or coins, while hand to mouth habits are the temporary attempts to consume or taste inedible objects. Unlike pica hand to mouth behaviors are often grown out of. Though pica behavior in children is often considered a leading reason lead-based paint is ingested the bioavailability of lead is much smaller in paint chips. When lead is dispersed in dust or soil the small particles can be inhaled, ingested, or absorbed by the skin. These small particles are more easily absorbed by the human body, therefore making lead more bioavailable in a dust (Mielke et al. 1998.) Over twenty government reports attribute lead contaminated soil or dust as a primary source of lead exposure in children (MN: MEERA, 1997.) Following safe gardening practices is the best way to reduce the bioavailability of lead in your 
urban gardens and can drastically decrease the chance of lead exposure in children.

\section{Conclusion}

Overall the Swiss Chard samples collected had very low levels of lead which would suggest that the Hillsboro Airport does not pose a significant threat of lead contamination to garden Swiss Chard in the area. Though the $\mathrm{Pb}$ levels were safe for consumption the CDC has not established any safe amount of lead in the human bloodstream, and due to leads tendency to bioaccumulate in living tissue it is recommended to use safe gardening practices to limit exposure to common urban pollutants.

\section{References}

Centers for Disease Control (CDC). 1991. Preventing Lead Poisoning in Young Children: A Statement by the Centers for Disease Control. Atlanta, GA: U.S.

Department of Health and Human Services.

Nriagu. 1998. Paleoenviornmental Research-tales Told in Lead. Science. (281): 1622-1623.

Mielke et al. 1998. Soil: An Important Pathway of Human Lead Exposure. Environmental Health Perspectives. 106 (1): 217-229.

Ryan et al. 2004. Reducing children's risk from lead in soil. Environmental Science technology. (41): 4164-4171.

Clark et al. 2008. Urban gardens: Lead exposure, recontamination mechanism and implications for remediation design.

Environmental Research. (107): 312-319.

Gomaa et al. 2002. Maternal Bone Lead as an Independent Risk Factor for Fetal Neurotoxicity: A Prospective Study. Pediatrics. (110): 110-118.

Center for Disease Control (CDC). 1997. Screening young children for lead poisoning: guidance for state and local public health officials. Atlanta, GA: U.S. Department of Health and Human Service.

Rabinowitz. 2005. Lead isotopes in five historic American lead smelters and refineries. The Science of the Total Environment. 346 (1-3): 138-148.

Nriagu. 1989. The Rise and Fall of Leaded Gasoline. The Science of the Total Environment. 92 (1990) 13-28.

U.S. Environmental Protection Agency. 1986. Air Quality Criteria for Lead. Environmental Criteria and Assessment Office. EPA 600/8-89 049F

Center for Disease Control (CDC). 1991. Strategic Plan for the Elimination of Childhood Lead Poisoning. Atlanta, GA: U.S. Department of Health and Human Service.

U.S. Environmental Protection Agency. 1998. A summary of studies addressing the source of soil-lead. In: Study abstracts. EPA 747-R-98-001B.

U.S. Environmental Protection Agency. 1996. Urban soil lead demonstration project volume I: EPA /600/p-93/001aF.

Lovestead et al. 2009. Application of the Advanced Distillation Curve Method to the 
Aviation Fuel Avgas 100LL. Energy Fuels. 23

(4): 2176-2183.

Kessler. 2013. Sunset for Leaded Aviation Gasoline? Environmental Health Perspective. 121(2): a54-a57.

Miranda et al. 2011. A Geospatial Analysis of the Effects of Aviation Gasoline on Childhood Blood Lead Levels. Environmental Health Perspectives. 119. (10): 1513-1516.

U.S. Environmental Protection Agency. 2009. Electronic Report on the Environment

ASTM International. 2005. Annual Book of ASTM Standards Section 5: Petroleum Products, Lubricants, and Fossil Fuels. 05.01. (1): D56-D3230.

Department of Environmental Quality: Air Toxics Science Advisory Committee (2015, February 18). Press release available from: http://www.oregon.gov/deq/FilterDocs/ats ac021815meetingminutes.pdf (accessed 05.06.2018)

Port of Portland - Hillsboro Airport () Press release available from: http://www.portofportland.com/HIO (accessed 10.01.2018)

Li et al. 2001. Heavy metal contamination of urban soils and street dusts in Hong Kong. Applied Geochemistry. (16): 1361-1368

Woolson. 1973. Arsenic phytotoxicity and uptake in six vegetable crops. Weed Science (21): 524-527

Cobb et al. 1999. Accumulation of Heavy Metals by Vegetables Grown in Mine Wastes. Environmental Toxicology and Chemistry. 19. (3): 600-607.
Rahlenbeck et al. 1999. Lead and cadmium in Ethiopian vegetables. Bull Environment Contamination Toxicology. (62) 30-33.

U.S. Enviornmental Protection Agency. 1986. Air quality criteria for lead. EPA 600/8/83/018F.

Sterrett et al. 1996. Influence of amendments on yield and heavy metal accumulation of lettuce grown in urban garden soils. Environmental Geochemistry Health. (18) 135-142.

Glorennec, P. 2006 Analysis and reduction of the uncertainty of the assessment of children's lead exposure around an old mine. Environmental Research. 100 (2): 150-158.

Baars et al. 2001. Re-evaluation of hyman toxicological maximum permissible risk levels. RIVM Report 711701025.

JECFA. 1999. In: Summary and Conclusions $53^{\text {rd }}$ Meeting. World Health Organization Joint FAO/OMS Expert Committee on Food Additives, Geneva. Available from:

http://jecfa.ilsi.org (accessed 04.25.2018.)

Center for Disease Control (CDC). 2007.

Advisory committee on childhood lead poisoning prevention (2007) interpreting and managing blood lead levels $<10 \mu \mathrm{g} / \mathrm{dL}$ in children a reducing childhood exposus to lead: recommendations of CDC's advisory committee on childhood lead poisoning prevention. Morbidity and Mortality Weekly Report 56 (RR-8.)

U.S. Enviornmental Protection Agency. 2006. Air Quality Criteria for Lead. EPA/600/R-5/144aF. 
Mielke et al. 1998. Soil Is an Important

Pathway of Human Lead Exposure.

Environmental Health Perspective. 106 (1):

217-229.

Reagan, PL. 1997. Direct Quotations of

Government Reports on Lead in Dust of All

Types. St Paul, MN: Midwest Environmental

Education and Research Association

(MEERA). 